\title{
TRUC or the Need for a New Microbial Classification
}

\author{
Didier Raoult \\ Unité de Recherche sur les Maladies Infectieuses et Tropicales Emergentes, Aix Marseille Université, \\ CNRS UMR 7278, IRD 198, INSERM 1095, Faculté de Médecine, Marseille, France
}

\section{Key Words}

Archaea - Bacteria - Eukarya - Megavirales - Mimivirus .

TRUC - Things Resisting Uncompleted Classifications

\begin{abstract}
Microbes were defined in the 19th century by L. Pasteur. Prokaryotes and eukaryotes, which are divided into two worlds of microbes, were introduced by E. Chatton in 1925. R. Woese divided this world into three domains based on ribosomal analysis (Bacteria, Archaea, and Eukarya). The discovery of Mimivirus and other Megavirales, that are microbes, led to divide the microbiological world into four branches. I introduced the name TRUC (Things Resisting Uncompleted Classifications) to accommodate the division in four of the currently known microbiological world.

๑) 2013 S. Karger AG, Basel
\end{abstract}

In the scientific world, classifications have always been made based on the tools available at a given time [1], and of course this also applies to microbes. The emergence of giant viruses, which have recently been tentatively grouped under the name Megavirales [2,3], raises the question of their position in the microbial world and is at the heart of heated debates. The history of the definition

\begin{tabular}{ll}
\hline KARGER & $\begin{array}{l}\text { ( } 2013 \text { S. Karger AG, Basel } \\
0300-5526 / 13 / 0566-0349 \$ 38.00 / 0 \quad \text { Karger }\end{array}$ \\
E-Mail karger@karger.com & $\begin{array}{l}\text { This is an Open Access article licensed under the terms of the } \\
\text { www.karger.com/int }\end{array}$ \\
& $\begin{array}{l}\text { Creative Commons Attribution-NonCommercial 3.0 Un- } \\
\text { ported license (CC BY-NC) (www.karger.com/OA-license), } \\
\text { applicable to the online version of the article only. Distribu- } \\
\text { tion permitted for non-commercial purposes only. }\end{array}$
\end{tabular}

of microbes began in 1878 when Pasteur, inspired by the surgeon Sedillot's proposal, coined the name 'microbe' to refer to microscopic organisms [4]. This name has persisted and conveys the fact that these agents are visible under an optical microscope and able to multiply. Unquestionably, from this point of view, giant viruses, including Mimivirus, are microbes (fig. 1). As the rabies and tobacco mosaic viruses happen to be invisible under the microscope and can pass through ultrafilters, the word 'ultravirus' was coined and degenerated into the term 'virus' in the 20th century, kicking viruses out of the world of microbes [4].

Subsequently, Chatton [5] divided the microbial world into two parts: the eukaryotes, which have a nucleus, and the prokaryotes, which have no nucleus. Subsequently, three domains were identified: Bacteria, Archaea, and Eukarya. This third step followed up on the work of Woese [6] who suggested a classification system based on the ribosome, which led to the creation of the concept of domains. It should be emphasized that this classification into domains is primarily based on the ribosome [4]. However, there are exceptions to this classification, as certain bacteria, such as Planctomycetes [7], Chlamydiaceae, and Verrucomicrobia, and some Archaea [8], have an internal membrane with compartmentalization comparable to a nucleus (fig. 1). Thus, the prokaryote/eukaryote definition 

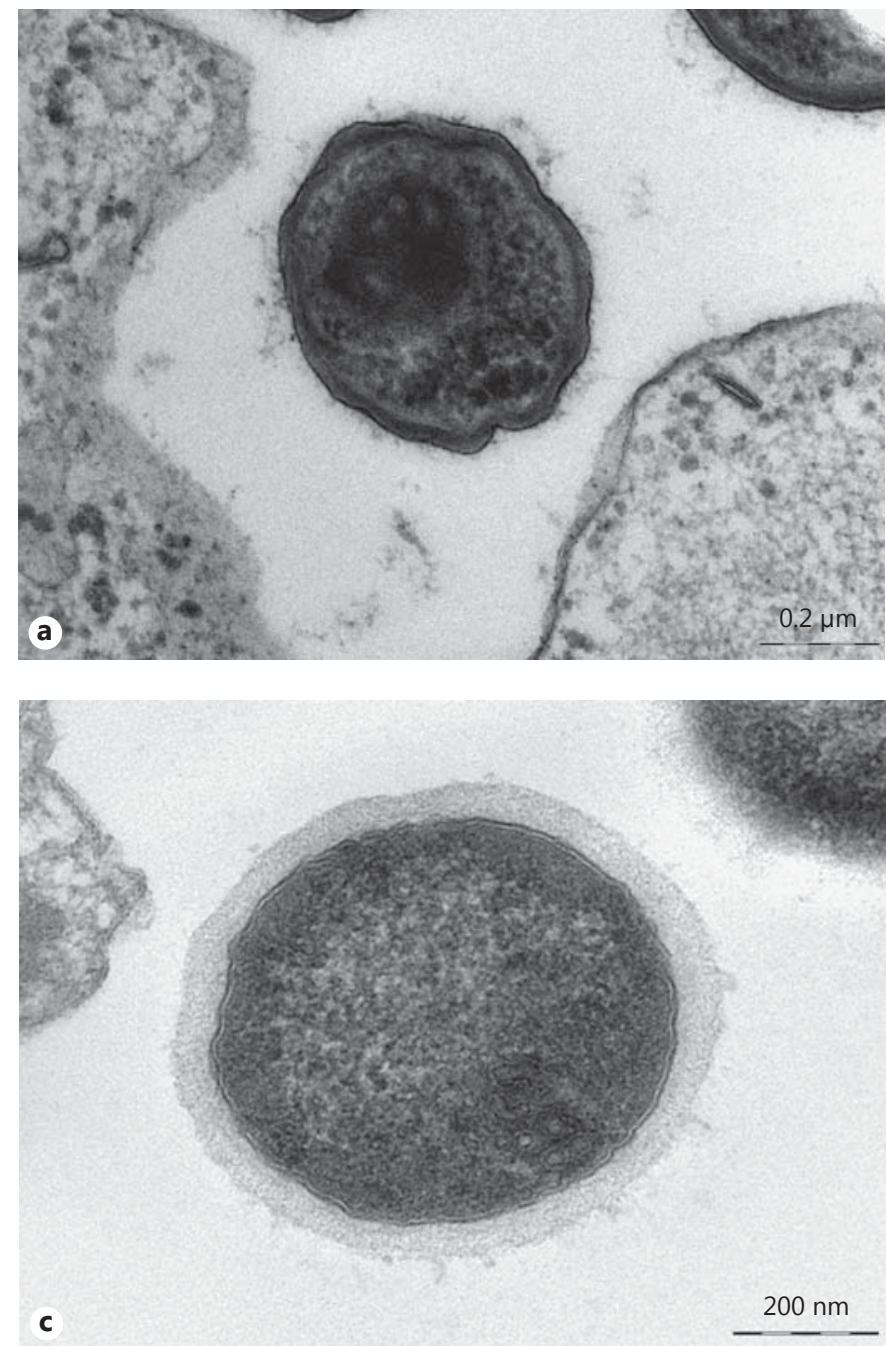

Fig. 1. Exceptions to the eukaryote/prokaryote and virus/microbe definitions. a TEM image of a Parachlamydia with an internal membrane (Bacteria looking like eukaryotes; courtesy of Gilbert Greub). b TEM image of a Verrucomicrobia with an internal membrane (Bacteria looking like eukaryotes; courtesy of Grégory Du-

is not entirely congruent with the current domain-based definition of microorganisms, as it includes, in 'eukaryotes', microorganisms that are classified in other domains by ribosomal analysis. Moreover, the current eukaryotes have a late origin compared to bacteria because they contain mitochondrial genes, which mostly originated from a-proteobacteria $[9,10]$. Moreover, the definition of eukaryotes based on the ribosome depends on the ribosome selected. The classification based on the ribosome of the chloroplasts of plants leads to a reclassification of plants among the cyanobacteria [10]. Finally, in the genomic era,
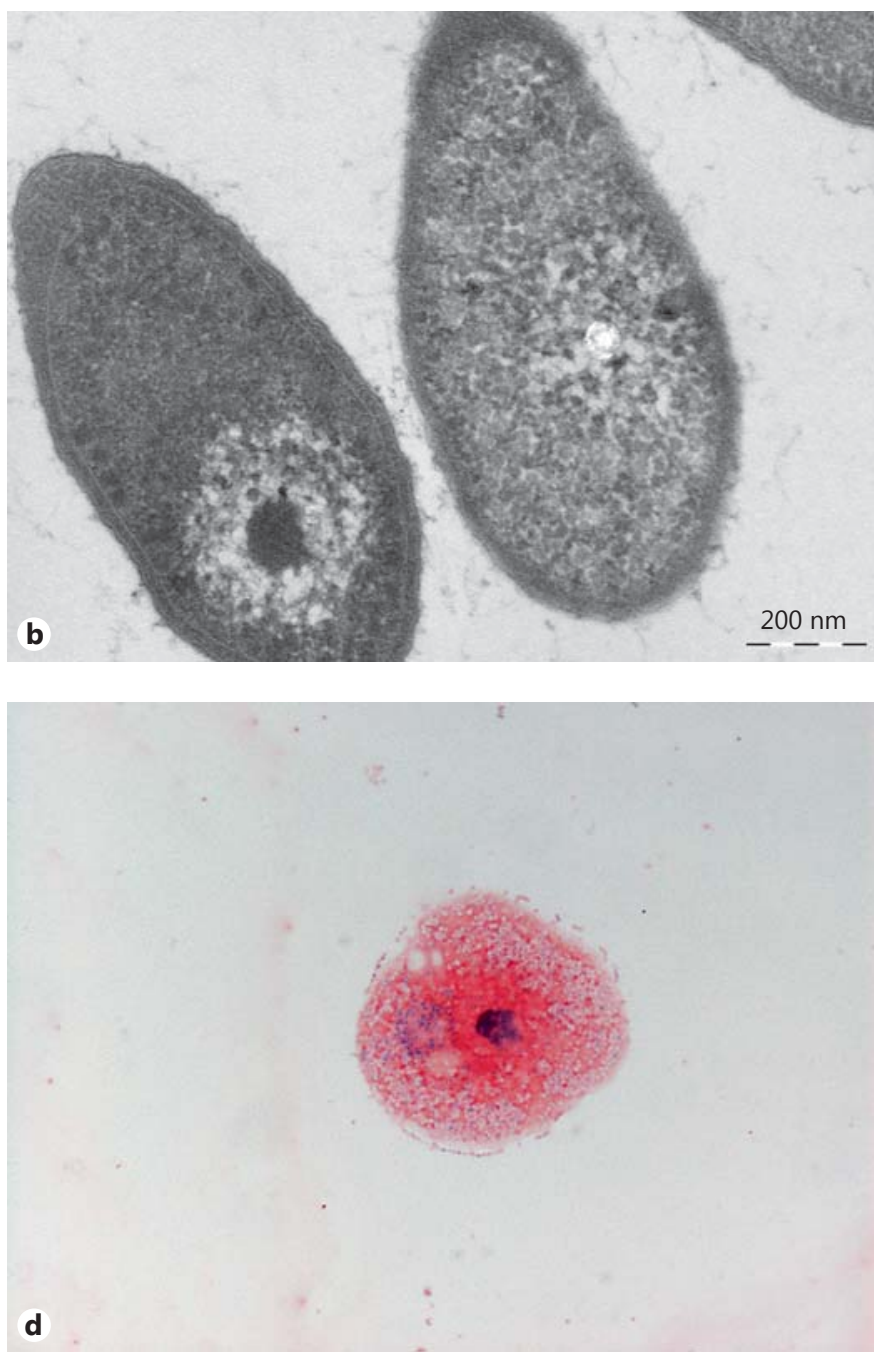

bourg). c TEM image of an Archaea with an internal membrane (like eukaryotes; courtesy of Saber Khelaifia). d Mimivirus, a Gram-positive-stained microbe looking like Bacteria with an amoeba (courtesy of Bernard La Scola). it has become obvious that organisms are genetic chimeras rather than homogeneous and that the 'tree of life' is the tree of the $16 \mathrm{~S}$ rDNA gene rather than that of the organisms $[11,12]$. Therefore, a classification into three domains based on the ribosome can in no way represent a complete definition of microorganisms.

The arrival of Mimivirus in the field of microbiology has not ceased to raise issues [13]. For a long time, this virus was mistaken for a Gram-positive bacterium because of its size and its Gram staining properties, making it look like a small bacterium [2] (fig. 1). Only the negativ- 


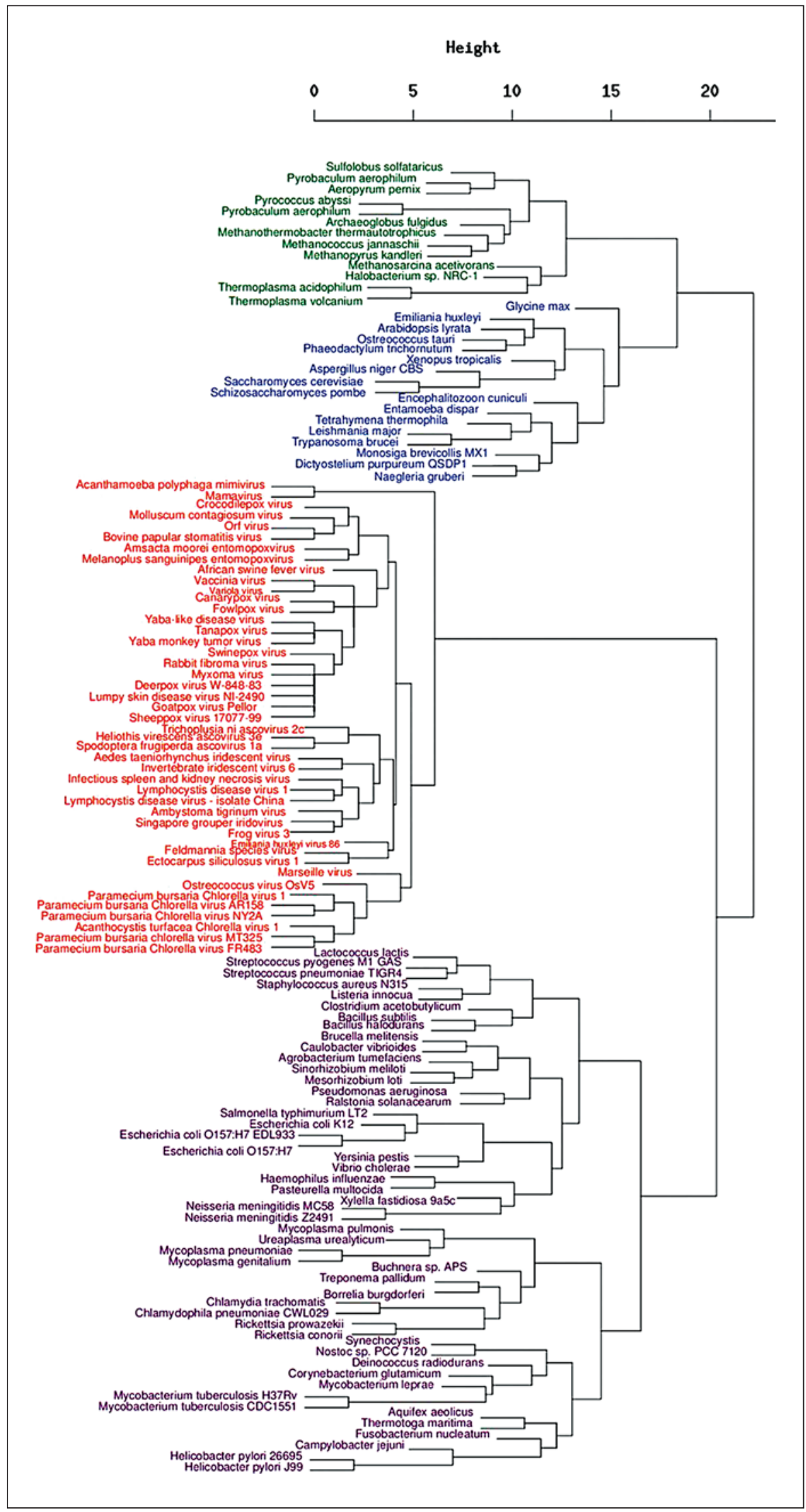

Fig. 2. Hierarchical clustering of Eukarya (blue), Bacteria (purple), Archaea (green), and NCLDVs (red) by phyletic pattern.

TRUC or the Need for a New Microbial Classification 
ity of tests performed with the $16 \mathrm{~S}$ rDNA 'universal' amplification tool led to the consideration that it was something else [14]. This finding was parallel to the discovery of a core set of genes common to large DNA viruses [15]. Finally, the subsequent stages of discoveries revealed that these large viruses had a common core set of genes, highlighting a common phylogenetic origin [16], associated with a specific genomic content, distinguishing them from the already defined three domains of life. Indeed, based on the banks of orthologous genes encoding information, we are able to cluster four groups of microbes: (i) Megavirales, (ii) Eukarya, (iii) Bacteria, and (iv) Archaea $[3,17]$. Moreover, the analysis of certain genes, such as RNA polymerase $B$, and more generally [18] the analysis of the proteomes of large viruses, led to clustering them and highlighted an ancestral origin of some genes at the same level as that of the three domains defined by ribosomal analysis $[19,20]$. When we merged the COG data banks (Cluster of Orthologous Genes) from viruses with that of Archaea, Bacteria, and Eukarya retaining informational genes, we observed that the four groups clustered independently (fig. 2) [17]. In addition, as in all microorganisms, the Megavirales contain genes imported from their hosts or from their neighbors when they infect a multi-infected cell, such as a phagocytic protist [21]. Finally, they have their own mobilome, including parasite viruses, the virophages [22], and the equivalent of transposons, the transpovirons [23]. Thus, as is the case for Bacteria and Archaea, they present a core genome, a mobilome, and imported sequences. The proportion of imported sequences is, as it happens, poor [24]. Most genes found in viruses are considered orphan genes [25].

The existence of these viruses is irreducible; it is a biological fact, and facts are 'stubborn'. We need to reflect on their position in the new world of microbiology. When comparing their genome content to that of microbes of an equivalent size, the only major difference concerns the translation apparatus and, more particularly, the ribosome [4]. It is not reasonable to exclude a microbe from the classification of microorganisms (in the etymological sense) because it does not contain a ribosome or because it is a parasite (as are some Bacteria, Archae, and Eukarya). Moreover, it appears that the greatest gene diversity on the surface of the earth originates from viruses. A classification of living beings that neglects $70 \%$ of the genetic information on earth does not seem reasonable [26].

I have suggested the existence of a fourth domain, but this raises issues $[2,18]$ because so far the domains have been defined based on the ribosome, which is absent from these viruses. Megavirales are undeniably microbes and are visible under the optical microscope [27], and I, therefore, suggest letting go of the classification based on three domains and adopt a classification scheme based on four items. Historically, this would follow the successive classification systems, which in the past contained one (the microbes), two (prokaryote/eukaryote), and three items (Eukarya/Bacteria/Archaea). Thus, the new fourth item could be named TRUC. TRUC, which is French for 'stuff (the acronym for Things Resisting Uncompleted Classifications), would include four microbiological items: Megavirales (and perhaps other large DNA viruses), Bacteria, Eukaryotes, and Archaea. Whatever one thinks of this new classification, whatever the violent reactions against this definition, giant viruses will remain. Nothing will prevent their reclassification in the world of microbiology. Ignoring their existence will prove impossible, all the more because sequences of these viruses are found everywhere in the water, in humans, and in soil, even though they have been neglected by many studies due to the common theory before the discovery of Mimivirus that $0.2-\mu \mathrm{m}$ filtration allows us to collect the entire world of viruses [28].

\section{References}

1 Popper K: The Logic of Scientific Discovery, ed 2. New York, Routledge Classics, 2007.

2 Raoult D, Audic S, Robert C, Abergel C, Renesto P, Ogata H, La SB, Suzan M, Claverie JM: The 1.2-megabase genome sequence of Mimivirus. Science 2004;306:1344-1350.

- 3 Colson P, de Lamballerie X, Fournous G, Raoult D: Reclassification of giant viruses composing a fourth domain of life in the new order Megavirales. Intervirology 2012;55: 321-332.
4 Raoult D, Forterre P: Redefining viruses: lessons from Mimivirus. Nat Rev Microbiol 2008;6:315-319.

5 Chatton E: Pansporella perplexa. Réflexions sur la biologie et la phylogénie des protozoaires. Ann Sci Nat Zool 1925;10(vii):184.

6 Woese CR: Bacterial evolution. Microbiol Rev 1987;51:222-270.

7 Fuerst JA, Sagulenko E: Beyond the bacterium: planctomycetes challenge our concepts of microbial structure and function. Nat Rev Microbiol 2011;9:403-413.
$>8$ Dridi B, Fardeau ML, Ollivier B, Raoult D, Drancourt M: Methanomassiliicoccus luminyensis gen. nov., sp. nov., a methanogenic archaeon isolated from human faeces. Int J Syst Evol Microbiol 2012;62:1902-1907.

$\checkmark 9$ Esser C, Ahmadinejad N, Wiegand C, Rotte C, Sebastiani F, Gelius-Dietrich G, Henze K, Kretschmann E, Richly E, Leister D, Bryant D, Steel MA, Lockhart PJ, Penny D, Martin W: A genome phylogeny for mitochondria among a-proteobacteria and a predominantly eubacterial ancestry of yeast nuclear genes. Mol Biol Evol 2004;21:1643-1660. 
10 Georgiades K, Raoult D: The rhizome of Reclinomonas americana, Homo sapiens, Pediculus humanus and Saccharomyces cerevisiae mitochondria. Biol Direct 2011;6:55.

11 Dagan T, Martin W: The tree of one percent. Genome Biol 2006;7:118.

12 Raoult D: The post-Darwinist rhizome of life. Lancet 2010;375:104-105.

13 Moreira D, Lopez-Garcia P: Ten reasons to exclude viruses from the tree of life. Nat Rev Microbiol 2009;7:306-311.

14 Raoult D, La SB, Birtles R: The discovery and characterization of Mimivirus, the largest known virus and putative pneumonia agent. Clin Infect Dis 2007;45:95-102.

15 Iyer LM, Balaji S, Koonin EV, Aravind L: Evolutionary genomics of nucleocytoplasmic large DNA viruses. Virus Res 2006;117:156184.

16 Boyer M, Madoui MA, Gimenez G, La SB, Raoult D: Phylogenetic and phyletic studies of informational genes in genomes highlight existence of a 4 domain of life including giant viruses. PLoS One 2010;5:e15530.

17 Boyer M, Madoui MA, Gimenez G, La SB, Raoult D: Phylogenetic and phyletic studies of informational genes in genomes highlight existence of a 4 domain of life including giant viruses. PLoS One 2010;5:e15530.
18 Wu D, Wu M, Halpern A, Rusch DB, Yooseph S, Frazier M, Venter JC, Eisen JA: Stalking the fourth domain in metagenomic data: searching for, discovering, and interpreting novel, deep branches in marker gene phylogenetic trees. PLoS One 2011;6:e18011.

19 Nasir A, Kim KM, Caetano-Anolles G: Giant viruses coexisted with the cellular ancestors and represent a distinct supergroup along with superkingdoms Archaea, Bacteria and Eukarya. BMC Evol Biol 2012;12:156.

20 LeGendre M, Arslan D, Abergel C, Claverie JM: Genomics of Megavirus and the elusive fourth domain of Life. Commun Integr Biol 2012;5:102-106.

21 Loftus B, Clarke M, Lohia A, et al: Genome of the environmental host Acanthamoeba castellanii highlights extensive lateral gene transfer and early evolution of pattern recognition and tyrosine kinase signalling. Genome Res 2013, E-pub ahead of print.

22 La SB, Desnues C, Pagnier I, Robert C, Barrassi L, Fournous G, Merchat M, Suzan-Monti M, Forterre P, Koonin E, Raoult D: The virophage as a unique parasite of the giant Mimivirus. Nature 2008;455:100-104.
23 Desnues C, La SB, Yutin N, Fournous G, Robert C, Azza S, Jardot P, Monteil S, Campocasso A, Koonin EV, Raoult D: Provirophages and transpovirons as the diverse mobilome of giant viruses. Proc Natl Acad Sci USA 2012; 109:18078-18083.

24 Forterre P: Giant viruses: conflicts in revisiting the virus concept. Intervirology 2010;53: 362-378.

25 Boyer M, Gimenez G, Suzan-Monti M, Raoult D: Classification and determination of possible origins of ORFans through analysis of nucleocytoplasmic large DNA viruses. Intervirology 2010;53:310-320.

26 Edwards RA, Rohwer F: Viral metagenomics. Nat Rev Microbiol 2005;3:504-510.

27 Colson P, Fancello L, Gimenez G, Armoungom F, Desnues C, Fournous G, Yoosuf N, Million M, La Scola B, Raoult D: Evidence of the Megavirome in Humans. J Clin Virol 2013, E-pub ahead of print.

28 Woese CR, Kandler O, Wheelis ML: Towards a natural system of organisms: proposal for the domains Archae, Bacteria, and Eukarya. Proc Natl Acad Sci USA 1990;87: 4576-4579. 